\title{
Needs Analysis for English for Specific Purpose course Development for Engineering Students in Korea
}

\author{
Hyun Hyo Kim \\ Kongju National University, Korea \\ hhkim@kongju.ac.kr
}

\begin{abstract}
In this era of globalization, English communication ability for engineers whose native language is not English has become as important as their major related abilities. As Korea has been implementing export-oriented economy policy, industries should be equipped with global communication tool, English. In engineering fields, the accreditation system for engineering education has been adopted to meet the global standard for engineers. Engineering majors provide more English courses in addition to the general English courses. The purpose of this paper is to provide detailed description of the needs analysis to develop an ESP course for engineering students in Korea. A needs analysis through survey questionnaire was done on three different groups: students group, engineering professors group, and industry workers group. With the triangulated source the data could get credibility and is expected to serve for ESP course development.
\end{abstract}

Keywords: ESP, engineering major, needs analysis, students, professors, industry workers, triangulated source

\section{Introduction}

Generally the most important ability in job placement would be major related abilities but English is regarded as one of the most important abilities in Korea regardless of job seekers' major fields. English communication ability has become a crucial qualification for a job applicant to be hired in Korea as well as abroad. That is also true in EU nations and Asian countries including China and Japan where English is not native language.

Engineers all around the world would find themselves use English for some aspect of their jobs. English is used in most international organizations and publications in engineering field and most engineers whose native language is not English would find disadvantages in their professional terms [1]. Beyond the difficult task of developing expertise in engineering, nonnative speakers must master English through continued English education, which some have estimated takes anywhere from 4-10 years of training to reach an average level of proficiency [2]. That fact would explain why the Accreditation Board for Engineering Education in Korea (ABEEK) wants engineering students to acquire English communication ability good enough to cooperate globally in their professional fields.

In Korea, one of the most active fields in the global job market is engineering fields including IT, civil engineering/construction, electricity/electronics. More engineering programs are implementing accreditation system. The purpose of engineering education accreditation system is to meet the global standard for engineers. In the year 2011, 651 programs in 97 universities and colleges are adopting the accreditation system in Korea. In a survey research, the industries answered "Practical English or Language related subject" is the most useful subject to get a job among the 'Specialized General Curriculum Subjects' in 
the accreditation system [3]. Most programs under the accreditation system provide two English subjects, one is general English and the other is usually engineering English or business English, "Practical English for Engineers" in Busan National Univ., "Engineering English" in Honam Univ. and "Engineering Technology English" in Kwangwoon univ. to list some of them. The general English courses are in the lower years and ESP courses are in the higher years of the curriculum, which are expected to help students to perform their career activities globally.

\section{Purpose}

The purpose of this research is to provide detailed description of the needs analysis to develop an ESP course for engineering students in Korea. To develop an ESP syllabus we need to understand the customers' needs. In this case, the customers are students, engineering professors and industries and the ESP course is supposed to serve for the specific purpose. The engineering programs undertaking accreditation system have their articulated goal of the program and the engineering professors best understand what kind of English education is needed accomplish the goal. As already seen in previous section, some engineering programs provide another English courses in addition to the basic general English course. In general English courses, it is hard to determine the students' learning needs. But for ESP courses, as needs from students as well as engineering professors are clear, a needs analysis to develop a course is important. Cowling(2007) found out Japanese engineering university graduate workers in leading industries lacked confidence in spoken English while they were good at reading and writing [4]. In Korea, situation would not be much different from that of Japan and we need to understand what the industries, engineering professors and students need from English course.

\section{Needs Analysis (NA)}

A needs analysis is to identify "what learners will be required to do with the foreign language in the target situation and how learners might best master the target language during the period of training" [5]. We should understand what the industries want from the students as prospective workers, and what the professors want from their students to meet the goal of each program, and the students' motivation to learn in English class.

\subsection{Sources of NA}

There are 5 sources for needs analyses in ESP: published and unpublished literature, learners, teachers and applied linguists, domain experts, and triangulated sources [6]. Among those sources, Long(2005) strongly suggested to use the triangulated sources. When more than two sources are used to get the data, the data is triangulated by those sources. In this paper, data was collected from three different groups_ students group, engineering professors group, and the industry workers group_ to get credibility of the interpretation.

The number of total respondents was 173: There were 99 students, 30 engineering professors, and 43 industry workers. First, students were 99 engineering major students in K university in Chungnam province. The second group was the 30 faculty members of engineering college, $\mathrm{K}$ university in Chungnam which participates in ABEEK(Accreditation Board for Engineering Education in Korea) accreditation program. The third group was engineering major industry workers in Chungnam and Gyonggi province. 43 industry workers responded the questionnaire. 


\subsection{Methods of NA}

There are many methods in NA such as Non-expert intuitions, Expert practitioner intuitions, interviews structured or unstructured, surveys and questionnaires, language audits, participant observation and so on.

This research used mainly questionnaire survey. Unstructured interviews were also done with two industry workers before designing questionnaire to have general understanding of what industries want. One interviewee was an industry director who also works for $\mathrm{K}$ University as an adjunct professor. He works for a medium sized manufacturing company with 3 overseas branches. Another interviewee was an industry worker in a leading company and he has around 10 years of career.

In designing questionnaire items, some data was referred to from $\mathrm{O}^{\prime} \mathrm{NET}^{1}$ (Occupational Information Network) system which provides job descriptions and describes and defines the abilities and knowledge required for various jobs. Kim (2007) used the job description of mechanical engineers from the O'NET to develop a technical English syllabus [7]. As the O’NET provides data for U.S. job market, some items on language ability, knowledge, work context, and work activity were adopted to make question items and rating scale was transformed.

The questionnaire consists of 14 question items and 11 items were same with three respondent groups. The different 3 items were about professors' majors, satisfaction level with the students' English ability and the specific English skill that is least satisfactory, in other words, needs to be developed most. For industries workers, the different 3 items asked the kind of overseas relationship their companies have and satisfaction level with the staff's English ability and their least satisfactory English skill. For the students, the 3 different items were about their grade year and asked if they study English other than English subject provided by the school and the reason they study that English.

\section{Results}

\subsection{General information}

Questionnaire items were divided into two major parts. One is to get general information which will help make the frame work of ESP course. The other is to get detailed information such as how important the specific English abilities and skills are and what levels of fluency are required with them and the frequency of a work context and importance of certain English activities. First, general information could be elicited from the questionnaire:

- Student distribution: 99 students responded the questionnaire and they were freshman 23, sophomore 35, junior 19 and senior 22.

- Study English other than curriculum subject: Asked if they study English in addition to the English subject, 54\% answered yes. Among them, 66\% answered the reason was to get a job. To trip abroad was $7 \%$ and as they are interested in foreign language was $6 \%$.

-Engineering Professors distribution: Among the 30, IT majoring were 20\%, computer science $17 \%$, mechanical engineering $13 \%$, electricity \& electronics $13 \%$, and others including chemical engineering and civil engineering were $37 \%$.

\footnotetext{
1 http://online.onetcenter.org O'NET is developed under the sponsorship of the U.S. department of labor/employment and training administration and provides occupational information including job descriptions, qualifications and expected range of wages.
} 
- Industry workers distribution: Among 43 industry workers, 9\% work for subsidiaries of foreign companies, $33 \%$ work for the companies with overseas branches, $31 \%$ work for the companies with overseas partner companies, $22 \%$ have no overseas partner companies.

- Satisfaction level: $63 \%$ of the engineering professors said they were not satisfied and $13 \%$ said very unsatisfactory with the students' English abilities. Industry workers, $67 \%$ of them said staff's English abilities are so-so, $11 \%$ were not satisfied and $4 \%$ said very unsatisfactory.

- Least satisfactory English skills: Engineering professors answered the least satisfactory students' English skills are speaking 53\% and reading 53\% and then writing 50\% and listening $43 \%$. Industry workers responded the least satisfactory English skills of the staff are speaking $73 \%$, listening $33 \%$, writing $29 \%$, and reading $24 \%$. Speaking skill is considered to be the least satisfactory and need to be developed.

- Needs for Engineering English: When asked to check in 5 point rating scale the needs for Engineering English subject in the university curriculum, students responded 3.70, engineering professors 4.10 and industry workers 4.26 , which show a statistically very meaningful difference. Students should recognize there are strong needs for engineering English. The main reason for students to study English is to get jobs and they don't feel any needs for Engineering English. Engineering professors showed very low level of satisfaction with students' English ability and have strong needs for Engineering English subject. Industry workers showed low level of satisfaction with staff's English ability. This results show that professors have higher level of expectation on the students' English abilities than the industry workers' have on the staff members'. On the least satisfactory English skills, both professors and industry workers chose speaking skill.

Engineering English with speaking skill much focused on is needed to meet the needs from the professors group and industry workers group. Even though students don't feel the needs for Engineering English, that will meet the students' needs as well because it will serve for their needs to get jobs.

When respondents were asked to check the most important item to be included in ESP course contents, students responded daily conversational English (50 students), general business English (24), and engineering contents (20). Engineering professors responded engineering contents (17 professors) daily conversational English (7) and general business English (5). Industry workers responded general business English (20 workers), daily conversational English (16), engineering contents (5). See the Table 1.

Table 1. The importance of the contents in Engineering English

\begin{tabular}{lrrrrr}
\hline Respondents & $\begin{array}{c}\text { daily } \\
\text { conversational } \\
\text { English }\end{array}$ & $\begin{array}{l}\text { engineering } \\
\text { contents }\end{array}$ & $\begin{array}{c}\text { general business } \\
\text { English }\end{array}$ & df & $\begin{array}{c}\text { Chi-Square } \\
\text { Tests }\end{array}$ \\
\hline Student & $50(53 \%)$ & $20(21 \%)$ & $24(26 \%)$ & 4 & .000 \\
Engineering & $7(23 \%)$ & $17(57 \%)$ & $5(17 \%)$ & \\
professors & $16(37 \%)$ & $5(12 \%)$ & $20(49 \%)$ & \\
$\quad$ Industry workers & 73 & 42 & 49 & \\
Total(172) & & & & \\
\hline
\end{tabular}

Students think daily conversational English (53\%) should be the most important content in Engineering English. And students think engineering contents (21\%) is not important in Engineering English. But engineering professors think quite differently from the students. Engineering professors think engineering contents (57\%) is the most important and then daily conversational English (23\%) is the next. It is quite natural for engineering professors to put 
emphasis on the engineering English. They understand engineering education should meet the global standard required by ABEEK in Korea and they need to cooperate globally in their major fields in the near future. So the results from the engineering professors reflect the future needs in advance as well as the current needs. Industry workers think general business English is the most important (42\%) and daily conversational English (37\%) is the next while they put less importance on the engineering contents (12\%). Industry workers seem to have difficulty when they are required to use English in e-mailing, meeting buyers, or talking on the phone using general business English and daily conversational English rather than technically oriented projects. From an open-end interview with an industry worker, he told that he is often required to write e-mails in English and finds it difficult. He meets foreign engineers but he can manage to communicate on the technical matters. He is not good at English speaking but both of them share the context and even broken English with key technical terms will make him understood.

As a conclusion, students need to understand the importance of general business English and need to be well motivated to learn if they plan to work for an industry. If they want to pursue their career as competitive global engineers with long term goals, they need to familiarize themselves with engineering contents as well. The students' needs for daily conversational English can be met by the General English course provided in the lower grade. ESP course provided in the higher grade can include general business English to meet industry workers' needs. Some engineering contents such as extracts for readings should be included to reflect engineering professors' view.

\subsection{Specific information}

The latter part of the questionnaire was designed to get specific information on the importance and required levels of English abilities, skills ${ }^{2}$ and work activity and work context frequency. Those questionnaire items were adopted from O’NET online. The data from O'NET was not taken as this research aims to develop ESP for engineering students in Korea.

6 English abilities were selected from the abilities needed for engineers and respondents were asked to check their importance level in 10 point rating scale. See the Table 2.

Table 2. Oneway-ANOVA of English Abilities Importance

\begin{tabular}{llccccr}
\hline & & $\mathrm{N}$ & Mean & $\begin{array}{r}\text { Std. } \\
\text { Deviation }\end{array}$ & $\mathrm{F}$ & Sig. \\
\hline \multirow{2}{*}{ Oral } & student & 98 & 8.6020 & 2.08450 & .059 & .943 \\
comprehension & professor & 30 & 8.5000 & 1.38340 & & \\
Written & industry & 41 & 8.4878 & 2.31432 & & \\
comprehension & student & 98 & 7.9286 & 1.77177 & 3.313 & .039 \\
& professor & 30 & 8.8000 & 1.27035 & & \\
Oral & industry & 40 & 8.4250 & 1.94656 & & \\
expression & student & 98 & 7.8163 & 2.03245 & .207 & .813 \\
& professor & 30 & 8.0667 & 1.72073 & & \\
Speech & industry & 40 & 7.7750 & 2.31481 & & \\
Clarity & student & 98 & 7.1122 & 1.97345 & .958 & .386 \\
& professor & 30 & 7.2000 & 1.82700 & & \\
\hline
\end{tabular}

2 Ability is the capacity to perform a task and also is a talent or quality enables you to do something. Skill is the learned capacity to perform a task effectively. A skill is a specific ability acquired by developing traits with study and training. 


\begin{tabular}{lllllll}
\hline Speech & student & 98 & 8.1633 & 1.79744 & 1.136 & .324 \\
recognition & Professor & 30 & 7.7000 & 1.82228 & & \\
& industry & 41 & 7.7073 & 2.36901 & & \\
Written & student (a) & 98 & 7.4286 & 1.92113 & 3.512 & .032 \\
expression & professor(b) & 30 & 8.3333 & 1.42232 & & \\
& industry(c) & 41 & 8.0488 & 1.93586 & & \\
\hline
\end{tabular}

There are 6 English abilities. The highest importance is 10 point. Oral comprehension, oral expression, speech clarity, and speech recognition distribute between 7-8 points and there is no statistically meaningful difference among the three groups. But there is statistically meaningful difference with written comprehension $(\mathrm{F}=3.313, \mathrm{P}=0.39)$ and written expression $(\mathrm{F}=3.512, \mathrm{P}=0.32)$. While professors $(8.80,8.33)$ and industry workers $(8.42,8.04)$ think those abilities are very important, students think less $(7.92,7.42)$. Writing is one of the most difficult skills for Korean students as they don't writes often. Students need to understand the importance of written comprehension and written expression as those are very useful communication skill especially when face-to-face meeting with foreigners is not possible.

Table 3. Oneway-ANOVA of Required Levels of English Abilities

\begin{tabular}{|c|c|c|c|c|c|c|}
\hline & & $\mathrm{N}$ & Mean & Std. Deviation & $\mathrm{F}$ & Sig. \\
\hline \multirow{3}{*}{$\begin{array}{l}\text { oral } \\
\text { comprehensi }\end{array}$} & student & 99 & 8.3232 & 2.28048 & \multirow[t]{3}{*}{.442} & \multirow[t]{3}{*}{.644} \\
\hline & professor & 30 & 7.9000 & 1.37339 & & \\
\hline & $\mathrm{n}_{\text {industry }}$ & 39 & 8.2564 & 2.35884 & & \\
\hline \multirow{3}{*}{\multicolumn{2}{|c|}{$\begin{array}{ll}\text { written } & \text { student } \\
\text { comprehension } & \text { professor } \\
\text { industry }\end{array}$}} & 99 & 7.6566 & 2.10520 & \multirow[t]{3}{*}{1.527} & \multirow[t]{3}{*}{.220} \\
\hline & & 30 & 8.3333 & 1.26854 & & \\
\hline & & 39 & 7.5385 & 2.36026 & & \\
\hline \multirow{2}{*}{\multicolumn{2}{|c|}{$\begin{array}{c}\text { student } \\
\text { oral expressionprofessor }\end{array}$}} & 99 & 7.6061 & 2.13722 & \multirow[t]{3}{*}{.232} & \multirow[t]{3}{*}{.793} \\
\hline & & 30 & 7.5000 & 1.73702 & & \\
\hline \multirow{4}{*}{$\begin{array}{l}\text { speech } \\
\text { clarity }\end{array}$} & industry & 39 & 7.8205 & 2.08846 & & \\
\hline & student & 99 & 7.2727 & 2.03950 & \multirow[t]{3}{*}{2.298} & \multirow[t]{3}{*}{.104} \\
\hline & professor & 30 & 6.8333 & 1.57750 & & \\
\hline & industry & 39 & 6.4872 & 2.18694 & & \\
\hline \multirow{3}{*}{$\begin{array}{l}\text { speech } \\
\text { recognition }\end{array}$} & student & 99 & 7.9697 & 1.88146 & \multirow[t]{3}{*}{1.812} & \multirow[t]{3}{*}{.167} \\
\hline & professor & 30 & 7.2333 & 1.86960 & & \\
\hline & industry & 40 & 7.5500 & 2.31992 & & \\
\hline \multirow{3}{*}{$\begin{array}{l}\text { written } \\
\text { expression }\end{array}$} & student & 99 & 7.2424 & 2.00556 & \multirow[t]{3}{*}{1.098} & \multirow[t]{3}{*}{.336} \\
\hline & professor & 30 & 7.6333 & 1.49674 & & \\
\hline & industry & 39 & 7.7179 & 1.90496 & & \\
\hline
\end{tabular}

There is no statistically meaningful difference among the three groups. The three groups regard the required levels of those 6 abilities are similar, 7-8 point.

Table 4. Oneway-ANOVA of English Skills Importance

\begin{tabular}{llcccccc}
\hline & & $\mathrm{N}$ & Mean & $\begin{array}{c}\text { Std. } \\
\text { Deviation }\end{array}$ & F & Sig. & Scheffe \\
\hline \multirow{2}{*}{ reading } & student & 99 & 7.4141 & 2.08498 & 2.980 & .054 & \\
comprehension & professor & 30 & 8.4000 & 1.47625 & & & \\
& industry & 40 & 7.4500 & 2.06249 & & & \\
active & student(a) & 99 & 8.1717 & 2.07040 & 4.516 & .012 & $a>b$ \\
listening & professor(b) & 30 & 7.8667 & 1.92503 & & & \\
& industry(c) & 40 & 6.9750 & 2.39109 & & & \\
writing & student & 99 & 7.0909 & 1.91178 & .371 & .690 & \\
& professor & 30 & 7.2333 & 1.75545 & & & \\
\hline
\end{tabular}




\begin{tabular}{lllllll}
\hline \multirow{5}{*}{ speaking } & industry & 40 & 6.8500 & 2.08228 & & \\
& student & 99 & 8.6566 & 1.77948 & .343 & .710 \\
& professor & 30 & 8.4000 & 1.40443 & & \\
\multirow{5}{*}{ negotiation } & industry & 41 & 8.4390 & 2.18001 & & \\
& student & 99 & 8.0000 & 2.04540 & .843 & .432 \\
& professor & 30 & 7.5000 & 2.33046 & & \\
persuading & industry & 40 & 7.6000 & 2.48895 & & \\
& student & 99 & 8.1212 & 2.03677 & 2.841 & .061 \\
& professor & 30 & 7.2667 & 2.49044 & & \\
education & industry & 41 & 7.2927 & 2.60042 & & \\
& student & 99 & 7.0101 & 2.07755 & 3.108 & .047 \\
& professor & 30 & 5.9333 & 2.08332 & & \\
\hline
\end{tabular}

There are 7 English skills and they varies in their importance levels from 5-8. There are statistically meaningful differences between active listening $(\mathrm{F}=4.516, \mathrm{P}=0.012)$ and education $\mathrm{F}=3.108, \mathrm{P}=0.047$ ). On the active listening 3 , students give the highest points (8.17) while industries give the lowest (6.97). On the education, students give the highest point (7.01) while industries give the lowest (6.40). Speaking skills get the highest points from all three groups, $8.65,8.40,8.43$ respectively. This result emphasizes the importance of speaking. There was a similar result in the former section, 4.1 general information, speaking skill was the least satisfactory by both engineering professors (53\%) and industry workers (73\%). Speaking skill is the most important and least satisfactory skill.

Table 5. Oneway-ANOVA of Required levels of English Skills

\begin{tabular}{|c|c|c|c|c|c|c|}
\hline & & $\mathrm{N}$ & Mean & $\begin{array}{c}\text { Std. } \\
\text { Deviation }\end{array}$ & $\mathrm{F}$ & Sig. \\
\hline \multirow{3}{*}{$\begin{array}{l}\text { reading } \\
\text { comprehension }\end{array}$} & student & 99 & 7.3838 & 2.12712 & 1.414 & .246 \\
\hline & professor & 30 & 8.0667 & 1.17248 & & \\
\hline & industry & 39 & 7.4103 & 2.13638 & & \\
\hline \multirow{3}{*}{$\begin{array}{l}\text { active } \\
\text { listening }\end{array}$} & student & 99 & 7.6768 & 2.24894 & 1.462 & .235 \\
\hline & professor & 30 & 7.9333 & 1.89251 & & \\
\hline & industry & 39 & 7.0769 & 2.41034 & & \\
\hline \multirow{3}{*}{ writing } & student & 99 & 7.2525 & 2.26483 & .467 & .628 \\
\hline & professor & 30 & 7.2667 & 1.72073 & & \\
\hline & industry & 39 & 6.8718 & 2.24991 & & \\
\hline \multirow{3}{*}{ speaking } & student & 99 & 8.3030 & 2.14502 & .036 & .965 \\
\hline & professor & 30 & 8.3333 & 1.80676 & & \\
\hline & industry & 39 & 8.4103 & 2.24450 & & \\
\hline \multirow{3}{*}{ negotiation } & student & 99 & 7.7778 & 2.24770 & 1.221 & .298 \\
\hline & professor & 30 & 7.2667 & 2.27328 & & \\
\hline & industry & 40 & 7.1750 & 2.53071 & & \\
\hline \multirow{3}{*}{ persuading } & student & 99 & 7.8485 & 2.27840 & 1.221 & .298 \\
\hline & professor & 30 & 7.1000 & 2.42615 & & \\
\hline & industry & 40 & 7.1250 & 2.51343 & & \\
\hline \multirow{3}{*}{ education } & student & 99 & 7.0606 & 2.35094 & 2.187 & .116 \\
\hline & professor & 30 & 6.2333 & 2.06253 & & \\
\hline & industry & 39 & 6.3333 & 2.57859 & & \\
\hline
\end{tabular}

3 Active listening is a skill to listen attentively and respond actively to improve mutual understanding in a conversation. When the listener focuses attention on the speaker, the speaker knows if the listener really understands or not. 
There is no difference among the three groups on the levels of 7 English skills. Speaking skill gets the highest points $8.30,8.33,8.41$ respectively that is the required level of speaking is the highest. Education skill gets the lowest points 7.06, 6.23, 6.33 respectively. According to the Table 4 and Table 5, speaking skill is very important and needs highest level.

Table 6. Oneway-ANOVA of English Work Context Frequency

\begin{tabular}{llcccccc}
\hline & & $\mathrm{N}$ & Mean & $\begin{array}{c}\text { Std. } \\
\text { Deviation }\end{array}$ & F & Sig. & Scheffe \\
\hline public & student & 95 & 3.7158 & 2.84965 & .224 & .800 & \\
address & professor & 30 & 4.1000 & 2.96357 & & & \\
& industry & 42 & 3.6667 & 3.29572 & & & \\
telephoning & student & 94 & 3.6489 & 3.28800 & .355 & .701 & \\
& professor & 30 & 4.2000 & 3.01033 & & & \\
& industry & 42 & 3.9048 & 3.21437 & & & \\
\multirow{5}{*}{ e-mailing } & student(a) & 95 & 3.7474 & 2.97853 & 4.478 & .013 & $a<b$ \\
& professor(b) & 30 & 5.5000 & 2.71331 & & & \\
& industry(c) & 41 & 4.8780 & 3.57208 & & & \\
letter/memo & student & 94 & 3.5426 & 2.94635 & 1.431 & .242 & \\
& professor & 30 & 4.6000 & 2.88396 & & & \\
\multirow{2}{*}{ face to face } & industry & 41 & 3.9024 & 3.20004 & & & \\
discussion & student & 94 & 3.2872 & 3.11646 & .727 & .485 & \\
& professor & 30 & 3.8667 & 2.90936 & & & \\
contact with & industry & 41 & 3.0000 & 2.87228 & & & \\
others & student & 94 & 3.4574 & 3.09583 & 2.021 & .136 & \\
\hline
\end{tabular}

Respondents were asked to check the frequency of the 6 work contexts in 10 point rating scale 4 . All 6 items distribute from 3-5 that is once in 6 months (3) to once in two months 5). There is a statistically meaningful difference on the frequency of e-mailing among the three groups, students (3.74), professors (5.50) and industries (4.87). Students need to recognize that they will write e-mail around once in two months.

Table 7. Oneway-ANOVA of English Work Activity Importance

\begin{tabular}{|c|c|c|c|c|c|c|c|}
\hline & & $\mathrm{N}$ & & $\begin{array}{l}\text { Std. } \\
\text { Deviation }\end{array}$ & $\mathrm{F}$ & Sig. & Scheffe \\
\hline \multirow{3}{*}{$\begin{array}{l}\text { English } \\
\text { communication with } \\
\text { co-workers }\end{array}$} & student(a) & 95 & 6.3263 & 2.74615 & \multirow[t]{3}{*}{5.364} & \multirow[t]{3}{*}{.006} & \multirow{3}{*}{$a>c$} \\
\hline & professor(b) & 30 & 6.1000 & 2.21826 & & & \\
\hline & industry(c) & 41 & 4.6585 & 3.11135 & & & \\
\hline \multirow{3}{*}{$\begin{array}{l}\text { English } \\
\text { communication with } \\
\text { customers }\end{array}$} & student(a) & 95 & 8.0632 & 2.26354 & \multirow[t]{3}{*}{4.774} & \multirow[t]{3}{*}{.010} & \multirow[t]{3}{*}{$a>c$} \\
\hline & professor(b) & 30 & 7.3333 & 2.42591 & & & \\
\hline & industry(c) & 42 & 6.6190 & 3.22303 & & & \\
\hline
\end{tabular}

There are statistically meaningful differences between student group and industry group in both two items, the English communication with co-worker and English communication with customers. Student group gives higher points $(6.32,8.06)$ than industry group $(4.65,6.61)$.

4 The work context frequency distributes from 1-5 in ONET. In this paper, that was transformed to 10 point rating scale to conform to other rating scales. The frequency points represent as follows: 1 is never, 2 is once in a year, 3 is once in 6 months, 4 is once in 4 months, 5 is once in two months, 6 is monthly, 7 is once in two weeks, 8 is weekly, 9 is twice a week, 10 is every day. 
All three groups think English communication with customers is more important than with co-workers.

Table 8. Oneway-ANOVA of Required level of English Work Activity

\begin{tabular}{llllllll}
\hline & & $\mathrm{N}$ & Mean & $\begin{array}{l}\text { Std. } \\
\text { Deviation }\end{array}$ & $\mathrm{F}$ & Sig. & Scheffe \\
\hline English & student(a) & 95 & 6.7158 & 2.51660 & 7.877 & .001 & $a>c$ \\
communication with & professor(b) & 30 & 5.8667 & 2.20866 & & & \\
co-workers & industry(c) & 41 & 4.7805 & 3.12660 & & & \\
English & student & 95 & 7.7368 & 2.41542 & 2.012 & .137 & \\
communication with & professor & 30 & 7.0333 & 2.48420 & & & \\
customers & industry & 42 & 6.8333 & 3.21518 & & & \\
\hline
\end{tabular}

There are statistically meaning differences between student group and industry group in the English communication with co-workers. Industry group think medium(4.78) level of English communication with co-workers is enough. All three groups think the level of English communication with customers needs to be higher than that of co-workers.

\section{Conclusion}

This paper plans to identify the needs for English for engineering students in Korea from multiple sources of students group, engineering professors group, and industry workers group. NA reveals what students, engineering professors, and industry workers think and require. Properly understanding their needs is essential in designing ESP course. The results are as follows:

1. Table 1 shows the most important content in Engineering English. Students choose daily conversational English (53\%), engineering professors choose engineering contents (57\%), industry workers choose general business English (49\%). Students need to understand the importance of general business English and need to be well motivated to learn if they plan to work for an industry. If they want to pursue their career as competitive global engineers with long term goals, they need to familiarize themselves with engineering contents as well.

2. Engineering professors have very low level of satisfaction on the students' English ability. Industry workers have low level of satisfaction on the staff's English ability.

3. Engineering professors and industry workers both chose speaking ability as the least satisfactory skill among 4 English skills, reading, writing, speaking, and listening.

4. Engineering professors and industry workers both recognize the needs for Engineering English, 4.10 and 4.26 respectively in 5 point rating scale.

5. Table 2 and Table 3 are on the importance and required level of 6 English abilities. While professors and industry workers think written comprehension and written expression are very important, students don't. Course should include ample writing parts to reflect the needs and students should understand the importance of written comprehension and written expression.

6. Table 4 and Table 5 are on the importance and required level of 7 English skills. Speaking is very important and required level is the highest. Considering speaking skill is the least satisfactory in results 2, ESP course should include ample portion on speaking. 
7. Table 6 is on the English work context frequency. There is a statistically meaningful difference on the frequency of e-mailing among the three groups, students (3.74), professors (5.50) and industries (4.87). Students need to recognize that they will write e-mail around one in two months. In designing the course syllabus, specific work situations reflecting the frequencies of each work should be included.

8. Table 7 and Table 8 are on the work activity importance and required level. All three groups think English communication with customers is more important and the required level is higher than with co-workers.

\section{Acknowledgements}

This research was supported by 2010 Research Year Program funded by Kongju National University (grant number 2009-1214 )

\section{References}

[1] T. Orr, "Assessing Proficiency in Engineering English", IEEE transactions on professional communication, vol. 45, no. 1, (2002), pp. 40-44.

[2] T. Orr and T. Aizuwakamatsu, "Constructing a Corpus of Fundamental Engineering English for Nonnative Speakers", Professional Communication Conference, IPCC 2002 Proceedings, Reflections on Communication, IEEE international, (2002), pp. 403-409.

[3] D. -j. Song, "A research on the proper curriculum to realize the developed phase of Mechanical Engineering education", $28^{\text {th }}$ Forum on Engineering Education, (2010).

[4] J. D. Cowling, "Needs analysis: Planning a syllabus for a series of intensive workplace courses at a leading Japanese company", English for Specific Purposes, vol. 26, (2007), pp. 426-442.

[5] R. West, "Needs analysis in language teaching", Language Teaching, vol. 27 no. 1, (1994), pp. 1-9.

[6] M. H. Long, "Methodological issues in learner needs analysis", Long M. H. (ed.) Second Language Needs Analysis, Cambridge: Cambridge University Press, (2005), pp. 19-76.

[7] H. H. Kim, "A Development of a Technical English Syllabus Based on the Job Descriptions", The Journal of Studies in Language, vol. 23, no. 1, (2007), pp. 45-63.

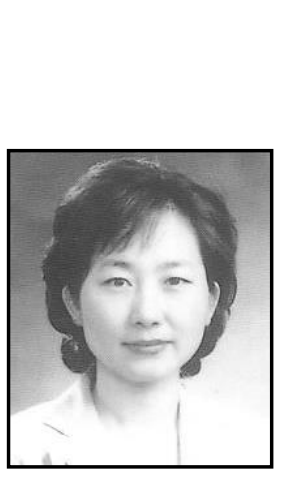

\section{Author}

\section{Hyun Hyo Kim}

She received her B.A., M.A. and Ph.D. degrees in Linguistics from Chungnam National University in 1985, 1988 and 1995, respectively. She has been a tenured professor in Department of English Language \& Literature, Kongju National University. She has interests in English for Specific Purposes and Semantics, especially cognitive Semantics. She is a director of the Modern Linguistic Society of Korea and also of Korea Academia-Industrial Cooperation Society. 